\title{
Content design and validation of a Standard Operating Procedure to provide pharmacotherapy follow-up for the elderly in Cuba
}

\author{
Irma Leonor Ortega López ${ }^{*}$, Niurka María Dupotey Varela ${ }^{1}$, Ivette Reyes Hernández ${ }^{1}$, Miguel \\ Ernesto Verdecia Rosés ${ }^{2}$, Yoenia Veranes Vera ${ }^{3}$, Natacha de la Concepción Sagaró Yiª ${ }^{3}$ Claudia \\ Lisset Núñez Pérez ${ }^{1}$, Arlettys Barroso Barrientos ${ }^{1}$
}

\author{
${ }^{1}$ Department of Pharmacy, University of Oriente, Santiago de Cuba, Cuba, " "Juan Bruno Zayas” Surgical Hospital, Santiago \\ de Cuba, Cuba, “América Labadí Arce” Nursing Home, Santiago de Cuba, Cuba
}

\begin{abstract}
Incorporating methodological tools that allow uniform and standardized development from the clinical pharmacy services to the Pharmaceutical Care practice, is nowadays a necessity. Considering the importance of pharmaceutical care provision to elderly patients, this manuscript introduces the design and content validation of a standard operating procedure to provide pharmacotherapy follow-up to the elderly in nursing homes in Cuba. The procedure was designed based on a deep analysis of documents relative to experiences focused on holistic care to elderly patients, criteria for the identification and assessment of potentially inappropriate prescriptions and the relationship between functional geriatric evaluation and the use of drugs. The content validation was conducted by a panel of experts, using the Delphi methodology, through two working sessions. In addition, we used Likert-type scale to evaluate the procedure by experts, in line with the indicators described. In general, the criteria issued by the experts were very appropriate and allowed us to modify, add or keep several elements of the instrument for the final version. The findings demonstrated that the instrument can be used at any level of health care.
\end{abstract}

Uniterms: Standardized Operating Procedure/validation. Pharmacotherapy Follow-Up/elderly/Cuba. Pharmaceutical Care/Cuba. Comprehensive Health Carefor/elderly. Delphi methodology.

\section{INTRODUCTION}

Demographic studies have shown an increase in the elderly population worldwide (Medeiros et al., 2011). In Cuba, people over six decades of life, account for $19,4 \%$ of the population (Oficina Nacional de Estadística e Información, 2015; Ministerio de Salud Pública, 2016). Life expectancy reaches 78.45 years (Oficina Nacional de Estadística e Información, 2013; Ministerio de Salud Pública, 2016) and is predicted that by 2050 , Cuba will be among the largest aging countries in the world (Jiménez, 2013). Consequently, healthcare strategies should be adopted to manage this situation.

The elderly represents the demographic sector needing higher health care services and which consumes a large amount of drugs, generating significant expenses, and sometimes this demographic group makes an

\footnotetext{
*Correspondence: I. L. Ortega López. Department of Pharmacy. Faculty of Natural and Exact Sciences. Universidad de Oriente. Patricio Lumumba S/N. Santiago de Cuba, Cuba. CP. 90500. E-mail: irma@uo.edu.cu
}

excessive use of either effective, dubious zero-efficacy drugs. Because of this, the elderly group is highly exposed to drug-related problems (DRPs), which can interfere with the outcome of the therapy (Reyes, Pérez, Martínez, 2006), and affect the quality of life of patients, causing the socalled negative outcomes associated with the medication (NOM).

Studies conducted in the United States, Canada and several European countries, show that in elderly outpatients, Potentially Inappropriate Medication (PIM) reaches $10 \%$ to $79 \%$, increasing hospitalizations and health expenses (Fick et al., 2003; Gongora et al., 2004; Fiolová et al., 2005; Barry et al., 2006; Jano, Aparasu, 2007; Sotoca et al., 2011; García-Gollarte et al., 2012; Blanco-Reina et al., 2014; Filomena et al., 2014). For this reason, it would of great impact to ensure the effectiveness of the drug treatments through the pharmacotherapy follow-up for these patients, which must be provided on a continuous, systematic and documented basis, in collaboration with the patients themselves and the other professionals in the system health, in order to achieve 
tangible results which may improve the quality of life of patients (Comité de Consenso, 2007).

Pharmacotherapy follow-up is a practice in which the pharmacist assumes the responsibility for the patient's drug-related problems aiming at achieving positive clinical outcomes. Several implicit methods have been described, for the development of the Pharmacotherapy follow-up service: Pharmacotherapy Workup (Cipolle, Strand, Morley, 2004); IASER Method (Climente, Jiménez., 2005); Dáder Method (Silvia- Castro et al., 2003; Faus, Amariles, Martínez, 2008); SOAP Approach (Cornelli et al., 2005) and the Medication Appropriateness Index (Hanlon et al., 1992; Gavilán et al., 2012).

All of these methods have been designed and implemented in different health contexts, being incorporated into standard operating procedures. However, in their manufacture, consideration was not given to the peculiarities of the elderly with respect to the treatment of the problems related to the great geriatric syndromes (Baster, 2010), the established criteria that define inappropriate prescriptions in these patients (Fick et al., 2012; American Geriatrics Society, 2015; Gallagher et al., 2008; Silveira et al., 2015) and the holistic care (biopsycho-social perspective), to solve the health problems of this population group (Merino, Miguel, Sanz, 2005).

On the one hand, the Medication Appropriateness Index was specifically developed to assess the adequacy of drug therapy in the elderly. Some authors describe it as a method for improving the prescription of specific drugs (Stuijt et al., 2008).Otherwise, in Cuban health system, the development of Pharmaceutical Care and Pharmacotherapy follow-up is limited. There are some professional factors that influence in this context: insufficiencies in methods and patterns of clinical performance, non-normalization and non-generalization of patient-centered activity within the health context, low availability of standardized operating procedures to provide Pharmaceutical Care services and scarce human and material resources. Therefore, the exercise is developed as the result of the spontaneity of a few professionals (Reyes, 2012; Dupotey, 2013). This transcends the fact that Cuban pharmacists have not been incorporated as members of the interdisciplinary team of geriatric patient care.

Taking into account the increasing population aging in Cuba (Oficina Nacional de Estadística e Información, 2015; Oficina Nacional de Estadística e Información, 2013) and the prediction of the percentage of fragile and in-need adults in a country ( $20 \%$ of the elderly population) (Fariñas, 2013), nursing homes are an important health care setting, especially for those patients with a high dependence. This group is exposed to the big consumption of drugs, associated to their medical, psychological, social and functional conditions, increasing the risk of medication-related problems, with consequences for the patient's health, the health care institutions and society in general. The great use of drugs in the elderly population and the morbidity and mortality associated with drugs, in the Cuban geriatric population, has been reported in several studies (Peña, Redondo, Groning, 2003; Reyes, Pérez, Martínez, 2006; Suárez, 2011). Albeit the development of research in the area of Pharmaceutical Care for the elderly is growing around the world, in Cuba, it is still insufficient.

Moreover, the design and implementation of the first Standard Operating Procedure (SOP) to provide Pharmacotherapy follow service, in Cuba, was developed by Reyes (2012). The instrument was designed and validated for inpatients pharmacotherapy follow-up, and is applicable to any population. But, its methodological structure does not respond to the identification and evaluation of main geriatric syndromes, associated with the use of drugs.

It has been demonstrated that it is necessary to meet the pharmacotherapy needs of the elderly, so as to prevent and resolve drug-related problems, by developing methodological tools, adapted to the bio-psychosocial peculiarities and the medication experiences of this population, which may allow for the provision of pharmacotherapy follow-up service, in a standardized and systematic manner, promoting the incorporation of pharmacists into interdisciplinary groups for geriatric patient care. In this regard, the manuscript presents the design evaluation and the content validity of a standard operating procedure to provide pharmacotherapy followup to elderly patients institutionalized in nursing homes, in Cuba.

\section{MATERIAL AND METHODS}

This research study applied the Delphi Method (Dalkey, 1967), to design and validate the contents of a Standard Operating Procedure in order to provide pharmacotherapy follow-up for the elderly, in nursing homes, in accordance with the Good Pharmacy Practice requirements (OPS, OMS, 1993) and the process approach specified in ISO9001: 2008 (ISO Standards, 2009). The study was conducted in the period from September 2014 to August2015.

The research design involved 5 phases: (1) the review of the literature and documentary analysis, (2) construction of the initial version of SOP and mailing the first-round assessment questionnaire to the expert 
committee, of the, (3) evaluation of the initial version of the SOP by the expert committee, (4) assessment of the revised SOP based on findings of round 1 and the expert panel feedback and the analysis of the evaluation criteria, (5) construction of the final SOP.

\section{Construction of standard operating procedure to provide pharmacotherapy follow-up to the elderly in nursing homes}

\section{(1) Review of the literature and documentary analysis}

The literature review included all relevant references published from 1990 to 2015, describing and analyzing the following terms: Pharmaceutical Care Philosophy, Pharmaceutical Care Methods and Services (Studies conducted by the groups of the University of Florida (United States), University of Minnesota (United States), University of Granada (Spain), University of Valencia (Spain), Pharmacotherapy Follow-Up Procedures and Methodologies, Drug-Related Problems, Medication and the Elderly, Comprehensive Care for the elderly, Potentially Inappropriate Medication used in the Elderly, and in the Elderly living in nursing homes. Doctoral Thesis of Cuban and foreign authors in the area of Pharmaceutical Care were also reviewed.

The search was made using MEDLINE and INFOMED databases (the most important websites of the Cuban Health System), identifying the appropriate references. Each article or bibliographic material was systematically reviewed by the researchers using a table to outline the following information: objective of the study, type of study design, research methodology used, and quality assurance indicators of the provided services.

\section{(2) Construction of the SOP initial version and forwarding to the expert committee}

After a documentary analysis of literature, three steps were taken: (1) a brainstorming session among researchers to select the working methods that were more in keeping with the research objectives, (2) the construction of the SOP initial version and (3) forwarding it to the expert committee.

\section{Ethical considerations}

At the beginning, potential participants with recognized expertise in pharmaceutical care research, pharmacotherapy follow-up; geriatric pharmacology, and clinical geriatric medicine, were invited by means of an invitation letter (via regular email)to be present and they were asked their consent to participate, through an informed consent form, to complete our survey. The members of the expert committee were selected from various geographic areas of Cuba.

The evaluation procedure was carried out anonymously to avoid the influence of leaders.

\section{Expert Selection}

The expert committee was formed taking into account the following inclusion criteria:

1. Bachelors of Science in Pharmaceutical Sciences or related professions, whether with a PhD. or MSc. and experience in the area of pharmaceutical care, pharmacotherapy follow-up or health care provision for the elderly.

2. Geriatricians or General Medicine Specialist with a degree in geriatrics regardless of the working place.

3. 5 years or more of experience in the health care sector or in teaching activity.

4. Get a competence coefficient between 0.5 and 1 $(0.5 \leq \mathrm{k} \leq 1)$.

The estimated sample included 13 specialists. The response rate for the initial invitation to participate as a panelist was $84,6 \%(11 / 13)$.

The competence of the experts was calculated using two methods: (1) Self-assessment of the potential members, in accordance with the methodology proposed by Hurtado (2002) and (2) Analysis of academic and scientific performance relative to the subject matter dealt with, through the curriculum vitae review, in the last five years. The indicators used for the evaluation are shown in Table I.

Experts whose competence coefficient through both methods presented the following combinations: HighHigh; High-Medium; Medium High; Medium-Medium, were finally included.

The Competence Coefficient (K) based on the analysis of each expert's curriculum, was calculated using the following equation:

$$
\mathbf{K}=\Sigma \mathbf{n}_{\mathrm{i}}=\left(\mathbf{n}_{1}+\mathbf{n}_{2}+\mathbf{n}_{3}+\mathbf{n}_{4}+\mathbf{n}_{5}+\mathbf{n}_{6}\right)
$$

where: $n_{i}$ : Value corresponding to each indicator $i$ (1 to 6 ).

The competence coefficient of the expert was rated high, medium or low using the following criteria:

$25 \leq \mathrm{K} \leq 30$ high competence coefficient

$18 \leq \mathrm{K} \leq 24$ medium competence coefficient

$12 \leq \mathrm{K} \leq 17$ low competence coefficient

The expert panel was finally composed of nine specialists, out of which $77.78 \%$ scored a high level of competence. All of them completed two rounds of the study. 
TABLE I - Indicators to assess the experts' competence based on the curriculum vitae (last 5 years)

\begin{tabular}{|c|c|c|c|}
\hline \multirow[b]{2}{*}{ Indicators } & \multicolumn{3}{|c|}{ IndicatorAssessment } \\
\hline & $\begin{array}{c}\text { High } \\
(5 \text { points) }\end{array}$ & $\begin{array}{c}\text { Medium } \\
\text { (3 points) }\end{array}$ & $\begin{array}{c}\text { Low } \\
(2 \text { points) }\end{array}$ \\
\hline Published papers (national or foreign) & $\geq 2$ per year & 1 per year & None \\
\hline $\begin{array}{l}\text { Participation in the committees for awarding scientific } \\
\text { degrees }\end{array}$ & $\geq 2$ per 5 years & 1 per 5 years & None \\
\hline Presentation of papers at scientific events & $\geq 2$ per year & 1 per year & None \\
\hline Teaching performance & $\begin{array}{l}\text { Postgraduate } \\
\text { Education }\end{array}$ & $\begin{array}{l}\text { Undergraduate } \\
\text { Education }\end{array}$ & Does not teach \\
\hline Awards and honors & $\geq 2$ in 5 years & 1 in 5 years & None \\
\hline Master degree supervisor and Examining Boards & $\geq 3$ in 5 years & $1-2$ in 5 years & None \\
\hline
\end{tabular}

(3) Evaluation of the first version of the SOP by the expert committee. First round

So as to validate the contents of the procedure (original version), experts reviewed the printed version of the initial draft document, and then completed an assessment questionnaire. The review was conducted using the Delphi method.

The criteria used for the evaluation of the SOP were taken from Moriyama, modified by Reyes in 2013 (Reyes et al., 2013) and adapted to the research objectives.

Criteria description:

- Reasonable and understandable: it makes reference to whether the item described from the technical point of view conceptually matches the subject matter and if understanding is adequate

- $\quad$ Traceability of the process: the SOP reflects the way in which the activity being developed is recorded and documented.

- Adequacy of the indicators: if the presence of each one of items included in the instrument, is justified.

- Sensitive to variations in the phenomenon being measured: if the instrument allows to discriminate each element of the proposed work systematics (for DRP-NOM characterization) and the respective indicators that are declared so as to assess the structure, processes and results of the service.

- Formal structure: that the SOP fulfills the established structure by the World Health Organization.

- Simplicity of the process: it makes reference to the simplicity with which each of the operations included in the process.

After reviewing the SOP, experts evaluated each indicator using the following Likert-Type Scale: strongly agreed (5); in agreement (4); neither in agreement nor in disagreement (3); in disagreement (2); and strongly disagreed (1). Each panelist had the opportunity to make suggestions to improve each indicator of the SOP.

After the analysis of the responses of the first round of the study, we examined each recommendation given so as to assess the modification or not of the SOP, and its subsequent evaluation in the second round. The mean rating and the relevant $95 \%$ confidence interval (CI) were calculated, for each indicator obtained from the first round of the assessment. For those indicators which $\mathrm{CI}>3$, the SOP was not modified. When the CI included 3, the SOP criteria was considered for a second round. Criteria whose $\mathrm{CI}<3$, involved the modification of the SOP. All the suggestions given by the experts, were summarized an evaluated for a second round, to reach a consensus among experts.

\section{(4) Assessment of the reviewed SOP (Second-round)}

In the 2 nd round, the new version of the printed SOP was sent to the experts, with all suggestions in a document attached. Experts' responses were evaluated in accordance with Likert-Type Scale of 5 points, following the values: $5=$ in strong agreement; $4=$ in agreement; $3=$ neither in agreement nor in disagreement; 2 = in disagreement and $1=$ in strong disagreement.

The mean rating and the appropriate $95 \%$ confidence interval (CI) per suggestions, were calculated. Those suggestions whose $\mathrm{CI}>3$, led to the SOP modification. When the IC $\leq 3$, the SOP was not modified.

Statistical analysis of the indicators in each round was developed by applying the Delphi Method Software (Hurtado, 2002).Each round was conducted in two weeks.

\section{(5) Final design of the SOP}

Once the responses and statistical analysis of the second round, were analyzed, the final version of the SOP was drawn up. 


\section{FINDINGS}

\section{Standard Operating Procedure to provide pharmacotherapy follow-up for the elderly (initial version)}

After reviewing the literature and the documentary analysis, the original version of the SOP was designed. The design included the following sections: Cover Page, Objectives, Applicability, Human resources involved, Reference documentation, Responsibilities, Definitions, Sequence of activities, Records, monitoring, Quality assurance of the Pharmacotherapy Follow-up and Annexes. The Objectives, Applicability, Human resources involved, Reference documentation and Responsibilities differ from the other SOP proposals, specifying that the instrument is for the elderly institutionalized in nursing homes.

Section Definitions included core concepts related to the pharmacotherapy follow-up service. Additionally, terms associated with the use of medications in the elderly were incorporated: the cascade prescription, elderly caregiver, individualized dose, duplicity, chronic illness, geriatric interdisciplinary team, geriatric functional assessment scale, polypharmacy in the elderly, appropriate and inappropriate prescriptions and geriatric syndromes.

Section "Sequence of activities" included core elements that characterize the elderly care, such as:

- Geriatric interdisciplinary team: Collaborative team, in which the main components are physicians, pharmacists and the nursing staff, who work together, cooperating for the achievement of the previously set therapeutic goals, considering the patient a member of the team and the center (together with his/her family) of the team. Each member should be highly familiarized with the tasks and responsibilities of the rest of the members, so that tasks and duties are, to some extent, interchangeable (Beers, Berkow, 2001). Thus, the inclusion of patients into the pharmacotherapy follow-up service can be promoted by any of its members.

- Functional geriatric evaluation: Based on the relationship between geriatric syndromes and drug use and the need for a holistic approach to the comprehensive care of the elderly, therefore it is considered a key element for case documentation.

- Identification and classification of DRPs: Criteria for the DRPs classification are shown in Table II. The list includes various types of DRP: prescription errors, dispensing errors, drug storage errors, administration errors, drug adverse reactions, and others.
Each drug-related problem identified, will allow to determine the therapeutic goal and the appropriate pharmacist's interventions to achieve it. The criteria used for identifying prescription errors were based on the potentially inappropriate prescriptions for the elderly (Fick et al., 2012; Gallagher et al., 2008).

- The systematic identification and classification of NOM, the care plan implementation and the pharmacotherapy follow-up evaluation: The steps to identify and classify NOMs and the assessment of the interventions outcome, are described, modifying Reyes' criteria in 2013 (Reyes et al., 2013) (Figures 1 and 2).

- Models conduct the initial interview and to draw up the pharmacotherapeutic profile for the elderly: The models included peculiarities of elderly associated to drug use: diseases with great prevalence in the elderly, major geriatric syndromes and drugs which they usually take. Besides, the pharmacotherapeutic profile was designed so as to achievea better traceability of the evaluation of the DRPs, the NOMs and the pharmacists' interventions, visits and consultations during patient therapy monitoring. In Section Quality Assurance of Pharmacotherapy Follow-up a system of indicators of structure, process and results, was established. They are shown in Table III.

\section{Assessment of the proposal of SOP by the expert committee (First Round)}

During the assessment of the proposal, all the evaluation criteria of the SOP sections showed CI values> 3 , leading to consensus among experts (Table IV). However, experts made some suggestions to improve the document in some of its parts: Cover Page, Sequence of activities, Quality Assurance of Pharmacotherapy Followup and Annexes.

\section{Assessment of the SOP proposal by the expert committee (Second Round)}

All the suggestions made the experts individually in the 1 st round, were evaluated by all in the 2 nd round. The results are shown in Table V.

Out of the 15 criteria to be assessed in the second round, 12 received favorable responses by the experts, finding consensus among them. Therefore, the contents of the SOP were modified, according to the suggestions made in some sections. The three remaining answers were unfavorable since there was not consensus among the experts. 
TABLE II - Criteria for the classification of DRPs

\begin{tabular}{|c|c|}
\hline DRPs Types & Description \\
\hline Prescribing errors & $\begin{array}{l}\text { - The patient uses a drug that is unnecessary. } \\
\text { - } \text { Drugs indicated, but not prescribed (when there is no contraindication to its use). } \\
\text { - Potentially inappropriate medication use in older adults: regardless of diagnoses or conditions. } \\
\text { - } \text { Intentially inappropriate medication use in older adults: considering diagnoses or conditions } \\
\text { - The dose, dosing interval or duration of treatment prescribed by the doctor is inadequate. } \\
\text { - The indication is inadequate. } \\
\text { - Individualization of treatment according to age, sex, weight (obesity or malnutrition value), } \\
\text { renal function, liver function, genetic polymorphism (assess whether patients can be slow or fast } \\
\text { metabolizers or can be fast or slow acetylators); allergies (eg. antibiotics, NSAIDs); Other health } \\
\text { problems that interfere with treatment and have not been taken into account between potentially } \\
\text { inappropriate medications. } \\
\text { - Incomplete prescription: default: the dosage form, strength or quantity. } \\
\text { - } \text { Incomprescribed master formula. } \\
\text { - Contraindications: contraindicated drug according to patient characteristics, taking into account the } \\
\text { geriatric syndromes. } \\
\text { - Treatment not cost / effective. } \\
\text { - Duplicate therapy: Prescription of two drugs from the same chemical structure or pharmacological } \\
\text { group with negative effects (non-benefit or harmful) for patient clinical condition. } \\
\text { Cascade prescription: drug prescription to treat adverse reactions caused by another drug. } \\
\end{array}$ \\
\hline Dispensing errors & $\begin{array}{l}\text { - Change dosage form or dosage strength. } \\
\text { - Wrong medicine. } \\
\text { - Insufficient information provided by the pharmacist about drug use } \\
\text { - Others }\end{array}$ \\
\hline Drug Storage errors & $\begin{array}{l}\text { - Non-compliance of storage or conservation standards: hygroscopicity, photosensitivity, inadequate } \\
\text { storage temperature, and others. }\end{array}$ \\
\hline Administration errors & $\begin{array}{l}\text { - } \text { Drug-drug interaction by co-administration } \\
\text { - } \text { Drug-food interaction (without prescriber's responsibility) } \\
\text { - } \text { Inadequate dosage form for the case. } \\
\text { - Non-compliance of the prescribed dose (missing or wrong) } \\
\text { - Speed inappropriate administration (parenteral drug use). } \\
\text { - Inadequate preparation conditions. } \\
\text { - } \text { Wrong patient administration } \\
\text { - } \text { Dilution or reconstitution inadequate } \\
\text { - } \text { Self-me of the administration route } \\
\text { - Medication non-adherence } \\
\end{array}$ \\
\hline Adverse drug reaction & $\begin{array}{l}\text { - Causative relationship between a health issue (undesirable effect) and the administration of one or } \\
\text { more drug. }\end{array}$ \\
\hline Others & $\begin{array}{l}\text { - Non-availability of drugs in pharmacy service. } \\
\text { - Any other drug-related problem that can cause NOM and has not been described previously. }\end{array}$ \\
\hline
\end{tabular}

Legend: DRPs: Drugs-Related Problems. NOM: Negative Outcomes associated with Medication. SAIDs: Nonsteroidal antiinflammatory drugs.

- $\quad$ Sections Cover Page, Object, Applicability and Human Resources involved were modified, because most of the experts considered that the SOP use is not restricted to nursing homes, and it can be applied at any level of health care. So, the proposal title was "Standard Operating Procedure to provide Pharma- 

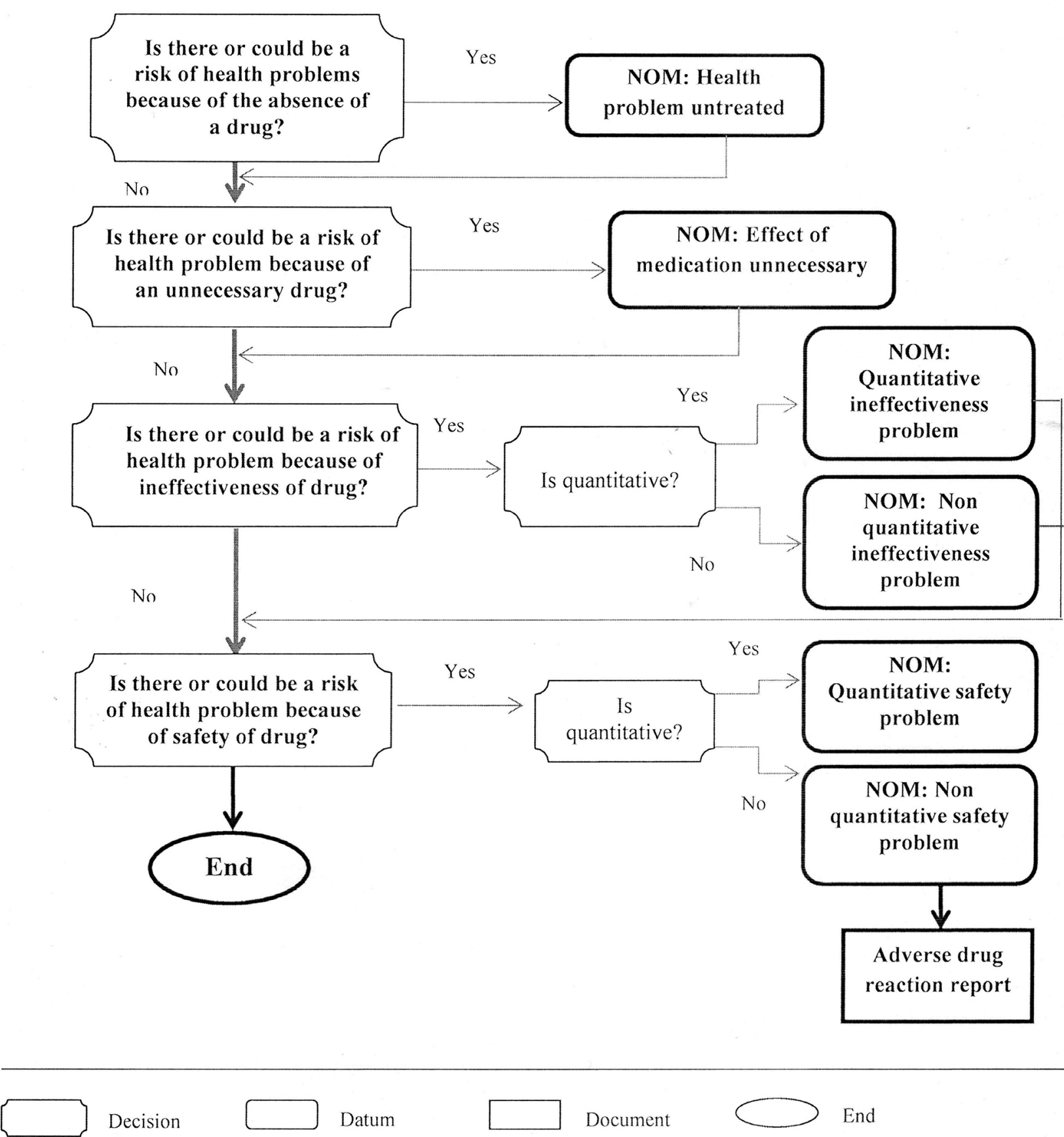

Decision
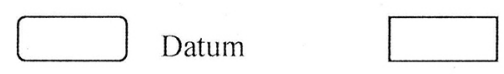

Document

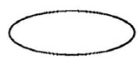

End

FIGURE 1 - Systematic detection and classification of NOM.

Legend: NOM: Negative Outcomes associated with Medication.

cotherapy Follow-up for the Elderly (PNT-SFTAM/ Acronym in Spanish language).

- Number "01" was included in the SOP code, being represented by the same acronym: as PNTSFTAM-01.

- The meaning of the auto shapes used in the Systematics for the detection and classification of NOMs (Figure 1) and in the Systematics for the evaluation of the pharmacist's interventions in the pharmaco- therapy follow-up (Figure 2), were specified.

- Three phases were explained in the Section Sequence of activities (Figure 3), which were described as follows:

o Initial assessment of the patient: To determine the patient's drug-related needs in the order of the indication, effectiveness and safety, service offering to the patient, creating of the pharmacoterapeutic profile, documenting the 




FIGURE 2 - Systematic evaluation of the pharmacist's interventions in the pharmacotherapy follow-up. Legend: DRP: Drugs-Related Problem. NOM: Negative Outcomes associated with Medication.

case and identifying drug therapy problems (DRPs) and negative outcomes associated with medication (NOMs).

O

Design and implementation of a therapeutic patient care plan: Establish goals of therapy, select appropriate interventions for: resolution of drug therapy problems, prevention of drug therapy problems and the evaluation of the results of interventions.

o Monitoring and evaluation of pharmacotherapy follow-up results in the patient: Include analysis of the final follow-up assessment (Assessment of the scope of therapeutic goals for the patient's care plan and the solu- tion or prevention of NOM) Satisfaction of the patient / caregiver is evaluated.

- The proposed changes relating to the incorporation of other types of DRPs (insufficient information provided by pharmacist about drug use, medication non-adherence and non-availability of drugs), were accepted as shown in Table I. Likely, the other suggestions issued by the experts were modified in the SOP.

\section{Construction of final SOP}

The diagram of the final SOP version is shown in Figure 4, according to the results of both rounds. 
TABLE III - Quality assurance indicators for Pharmacotherapy Follow-up service

\begin{tabular}{ll}
\hline Component & Indicators /description \\
\hline $\begin{array}{l}\text { Availability of professionals }\left(I_{1}\right): \text { To estimate the real availability of pharmacists providing } \\
\text { pharmacotherapy follow-up. }\end{array}$ \\
\hline
\end{tabular}

Training of professionals $\left(\mathbf{I}_{2}\right)$ : To estimate percentage of pharmacists with training program in pharmacotherapy follow-up activity.

Structure Time dedicated on pharmacotherapy follow-up $\left(\mathbf{I}_{3}\right)$ : To estimate the average time required by a pharmacist in pharmacotherapy follow-up. The interview time, study time and intervention time were included.

$\overline{\text { Availability of literature }\left(\mathbf{I}_{4}\right) \text { : To assess the available literature versus the suggested literature to provide }}$ the service.

DRPs per patient in pharmacotherapy follow-up $\left(\mathbf{I}_{5}\right)$ : To estimate the number of DRPs per patient in pharmacotherapy follow-up.

DRPs per validated medication order $\left(\mathbf{I}_{6}\right)$ : To estimate the number of DRPs per validated medication order.

Prescribing errors per validated medication order $\left(\mathbf{I}_{7}\right)$ : To estimate the number of Prescribing DRPs per validated medication order.

Dispensing errors per validated medication order $\left(\mathbf{I}_{8}\right)$ : To estimate the number of Dispensing DRPs

Process $\quad$ per validated medication order.

Administration errors per validated medication $\operatorname{order}\left(\mathbf{I}_{9}\right)$ : To estimate the number of Administration DRPs, per validated medication order.

Drug Storage errors per validated medication $\operatorname{order}\left(\mathbf{I}_{10}\right)$ : To estimate the number of Storage DRPs, per validated medication order.

Adverse Drug Reactions detected per validated medication order $\left(I_{11}\right)$ : To estimate the number of ADR-DRP detected, per validated medication order.

Pharmacist's interventions acceptance rate $\left(\mathrm{I}_{12}\right)$ :To estimate the rate of acceptance of the pharmacist's interventions.

Impact of pharmacist's interventions associated to NOMs $\left(I_{13}\right)$ : To estimate the impact of the pharmaceutical interventions in the resolution of NOMs.

Outcomes

Appropriateness of pharmacist's interventions for suspected NOMs $\left(\mathrm{I}_{14}\right)$ : Estimate the impact of the pharmaceutical interventions in preventing NOMs.

Patient's satisfaction $\left(\mathbf{I}_{15}\right)$ : Estimate the degree of satisfaction of patients and/or family.

Healthcare provider's satisfaction $\left(\mathbf{I}_{16}\right)$ : Estimate the degree of satisfaction of the healthcare providers in the interdisciplinary team.

Legend: ADR: Adverse Drugs Reactions; DRPs: Drugs-Related Problems; NOM: Negative Outcomes Associated with Medication.

\section{DISCUSSION}

\section{Proposed Standard Operating Procedure to provide pharmacotherapy follow-up to the elderly}

The conceptual framework of the first SOP version corresponds to the theoretical and methodological elements of an organizational system designed to provide Pharmacotherapy follow-upservice for the elderly in nursing homes. It takes into account some relevant references in this area, conducted by Gutiérrez (2006),
Reyes et al. (2013), Reyes (2012) and Dupotey (2013). Gutiérrez, made an important contribution to the Health System of Spain, who developed Quality Operating Procedures for the healthcare activities in community pharmacies.

In Cuba, it is worth highlighting the research conducted by Reyes (2012), Reyes et al. (2013) and Reyes et al. (2014) who developed a systemic approach to implementing pharmaceutical care services in hospitals. A SOP to provide pharmacotherapy follow-up at this level of health care, was validated. These works present a system of the vital relationships between patient-drug, 
TABLE IV - Assessment results by the expert committee (First Round)

\begin{tabular}{|c|c|c|}
\hline Criteria & Mean [IC] & Suggestions by the experts \\
\hline \multirow{2}{*}{ Reasonable } & \multirow{2}{*}{$\begin{array}{c}4.44 \\
{[4.91,3.97]}\end{array}$} & - To define stages or phases in the Pharmacotherapy follow-up process. \\
\hline & & - To clarify the usefulness of the functional geriatric assessment scale. \\
\hline \multirow{3}{*}{ Traceability } & \multirow{3}{*}{$\begin{array}{c}4,55 \\
{[\mathbf{5 . 0 0}, \mathbf{4 . 0 8}]}\end{array}$} & - To include the brachial data and abdominal circumference of patient. \\
\hline & & - To include the homeopathic treatment in the pharmacological anamnesis. \\
\hline & & $\begin{array}{l}\text { - To include as pharmacist's intervention the suggestion for determining and } \\
\text { monitoring biochemical tests. }\end{array}$ \\
\hline \multirow{6}{*}{ Adequacy } & \multirow{6}{*}{$\begin{array}{c}4.66 \\
{[4.98,4.34]}\end{array}$} & $\begin{array}{l}\text { - To include in dispensing errors "insufficient information provided by the pharmacist } \\
\text { about the use of the drug". }\end{array}$ \\
\hline & & - To include in administration errors "Medication non-adherence". \\
\hline & & - To include in other DRPs "non-availability of drugs in pharmacy service". \\
\hline & & $\begin{array}{l}\text { - To specify the standard number of pharmacists who provide pharmacotherapy } \\
\text { follow-up service. }\end{array}$ \\
\hline & & - To describe the standard average time of pharmacotherapy follow-up service. \\
\hline & & - To define the standard recommended literature. \\
\hline Sensitivity & $\begin{array}{c}4,66 \\
{[4.98,4.34]} \\
\end{array}$ & - To record all types of ADR, not only moderate and severe. \\
\hline \multirow{3}{*}{ Structure } & \multirow{3}{*}{$\begin{array}{c}4,77 \\
{[\mathbf{5 . 0 0}, \mathbf{4 . 4 9}]}\end{array}$} & $\begin{array}{l}\text { - To specify in the SOP title, that the instrument will be developed for elderly patients } \\
\text { in nursing homes. }\end{array}$ \\
\hline & & - To assign to the SOP, an identification code, for further modifications. \\
\hline & & - To clarify the meaning of the auto shapes used in the diagrams. \\
\hline Simplicity & $\begin{array}{c}4,33 \\
{[4.78,3.88]}\end{array}$ & - \\
\hline
\end{tabular}

Legend: ADR: Adverse Drugs Reactions. DRPs: Drugs - Related Problems.CI: confidence interval.

the pharmacist and the others health team members. The structure, the process and the outcomes are identified as quality components of the system, connected with all clinical services developed by the pharmacist.

Another theoretical reference for this research was developed by Dupotey (2013), who presents a new paradigm for the improvement of pharmaceutical care in Cuba, based on a comprehensive vision and holistic approach to provide Pharmaceutical Care by pharmacists, with the integrated participation of the Cuban Health System managers, health providers, academics, and patients. This paper highlights the evaluation of the biopsycho-social condition of the patient, to understand its drug-related problems. This is an essential aspect to be considered in the healthcare service provided for the elderly, because drug therapy in geriatrics requires a more humanistic approach than just a clinical perspective, centered in the elderly patient as an individual. (Merino, Miguel, Sanz, 2005).

The SOP proposal defends geriatric patient care, not only from the harmonic analysis of their clinical condition and use of drugs based on the inadequacy of medication criteria (Fick et al., 2012; American Geriatrics Society, 2015; Gallagher et al., 2008; Silveira et al., 2015; Holt, Schmiedl, Thurmann, 2010), and its relationship with geriatric syndromes. The SOP reveals the need of incorporating the bio-psychosocial condition of the patient, to obtain the necessary holistic assessment for the elderly, in a greater contribution and relevance of the pharmacist to solve the health problems of this particular population group, which is growing at an accelerated pace. (Oficina Nacional de Estadística e Información, 2013).

Likewise, a quality assurance system in the SOP, incorporates the structure, process and outcomes indicators, which allow the evaluation of pharmacotherapy follow-up service for the elderly. This contributes to the continuous improvement of the provided service, responding to the World Health Organization (WHO)'s statements that mentions: ... health systems should support and enhance the implementation and practice of pharmaceutical care by measuring, evaluating and improving pharmacy practice activities, using the 
TABLE V - Assessment results by experts in the second round

\begin{tabular}{|c|c|c|}
\hline Criteria & Mean $[\mathrm{IC}]$ & Result \\
\hline $\begin{array}{l}\text { 1. To specify in the SOP title, that the instrument will be developed for elderly patients } \\
\text { in nursing homes. }\end{array}$ & $\begin{array}{c}3,25 \\
{[4.40,2.10]}\end{array}$ & Not modified \\
\hline 2. To assign to the SOP, an identification code for further modifications.(01) & $\begin{array}{c}4,33 \\
{[4.89,3.77]}\end{array}$ & Modified \\
\hline 3. To clarify the meaning of the autoshapes used in the diagrams. & $\begin{array}{c}4,44 \\
{[5.00,3.58]}\end{array}$ & Modified \\
\hline $\begin{array}{l}\text { 4. To describe stages or phases in the Pharmacotherapy follow-up process, in the } \\
\text { "Sequence of activities" section. }\end{array}$ & $\begin{array}{c}4,11 \\
{[4.71,3.51]}\end{array}$ & Modified \\
\hline $\begin{array}{l}\text { 5. To clarify the usefulness of the functional geriatric assessment scale, in the Section } \\
\text { "Case Documentation " }\end{array}$ & $\begin{array}{c}4,25 \\
{[4.96,3.54]}\end{array}$ & Modified \\
\hline $\begin{array}{l}\text { 6. To include in dispensing errors "insufficient information provided by pharmacist } \\
\text { about the use of the drug". }\end{array}$ & $\begin{array}{c}4,33 \\
{[5.00,3.61]}\end{array}$ & Modified \\
\hline 7. To include in administration errors "Medication non adherence". & $\begin{array}{c}4,55 \\
{[5.00,3.89]}\end{array}$ & Modified \\
\hline 8. To include in other DRPs "non-availability of drugs in the pharmacy service". & $\begin{array}{c}4,22 \\
{[4.93,3.51]}\end{array}$ & Modified \\
\hline 9. To record all types of ADR, not just moderate and severe. & $\begin{array}{c}4,66 \\
{[4.98,4.34]}\end{array}$ & Modified \\
\hline $\begin{array}{l}\text { 10. In the structure indicator "Availability of the professionals (I1)" to define the } \\
\text { standard number of pharmacists who provide pharmacotherapy follow-up service. }\end{array}$ & $\begin{array}{c}4,66 \\
{[4.98,4.34]}\end{array}$ & Modified \\
\hline $\begin{array}{l}\text { 11. In the structure indicator "Pharmacotherapy follow-up Time }\left(\mathrm{I}_{3}\right) \text { " to define the } \\
\text { standard average time of the Pharmacotherapy follow-up service. }\end{array}$ & $\begin{array}{c}3.77 \\
{[4.56,2.99]}\end{array}$ & Not modified \\
\hline $\begin{array}{l}\text { 12. In the Structure indicator "Availability of the literature }\left(\mathrm{I}_{4}\right) \text { ", to define the standard } \\
\text { recommended literature. }\end{array}$ & $\begin{array}{c}3,88 \\
{[4.98,2.78]}\end{array}$ & Not modified \\
\hline $\begin{array}{l}\text { 13. In the section "Initial Interview Form" to include the brachial data and abdominal } \\
\text { circumference of patient, to determine the body mass index in the bedridden elderly. }\end{array}$ & $\begin{array}{c}4,77 \\
{[5.00,4.49]}\end{array}$ & Modified \\
\hline 14. In Annex, to include the homeopathic treatment in the pharmacological anamnesis. & $\begin{array}{c}4,33 \\
{[4.78,3.88]}\end{array}$ & Modified \\
\hline $\begin{array}{l}\text { 15. In Annex, to include as a pharmacist's intervention, the suggestion for determining } \\
\text { and monitoring biochemical tests. }\end{array}$ & $\begin{array}{c}4,66 \\
{[4.98,4.34]}\end{array}$ & Modified \\
\hline
\end{tabular}

Legend: ADR: Adverse Drugs Reactions. DRPs: Drugs - Related Problems.CI: Confidence Interval.

conceptual framework of continuous quality improvement. (Widenmayer, Summers, Mackie, 2006).

The designed indicators in the SOP, responding to the Donadebian quality approach (Donadebian, 1988). These indicators consider the three phases of the Sequence of activities: Initial assessment of the patient; Design and implementation of a therapeutic patient care plan and evaluation of results in the patient.

Regarding the structure indicators, there are no differences when comparing it with the one proposed by Reyes et al. (2013). However, the process indicators incorporate others which are not addressed by this author, which are identified as $\mathrm{I}_{5}, \mathrm{I}_{7}, \mathrm{I}_{8}, \mathrm{I}_{9}, \mathrm{I}_{10}$ and $\mathrm{I}_{11}$ These are oriented to determine the DRPs per validated medication order, specifically those related to the prescription, dispensing, administration, storage and ADR and thus, to design activities in order to improve the staff training and process control. The NOM is the clinical consequence of the DRP, and the pharmacist's responsibility is to prevent and to resolve them. One NOM may be associated with multiple DRPs. From this point of view, the evaluation of NOM was excluded of the process indicators proposed by Reyes and incorporated as outcome indicators.

The impacts of the pharmacist's interventions to resolve NOM $\left(\mathrm{I}_{13}\right)$ and to prevent $\mathrm{NOM}\left(\mathrm{I}_{14}\right)$ were included. Both indicators express the pharmacist's role in the improvement of the pharmacotherapy and if this professional is able to gain benefits with the patient's care plan implemented. There are so many examples of these indicators, whose usefulness in evaluating the 


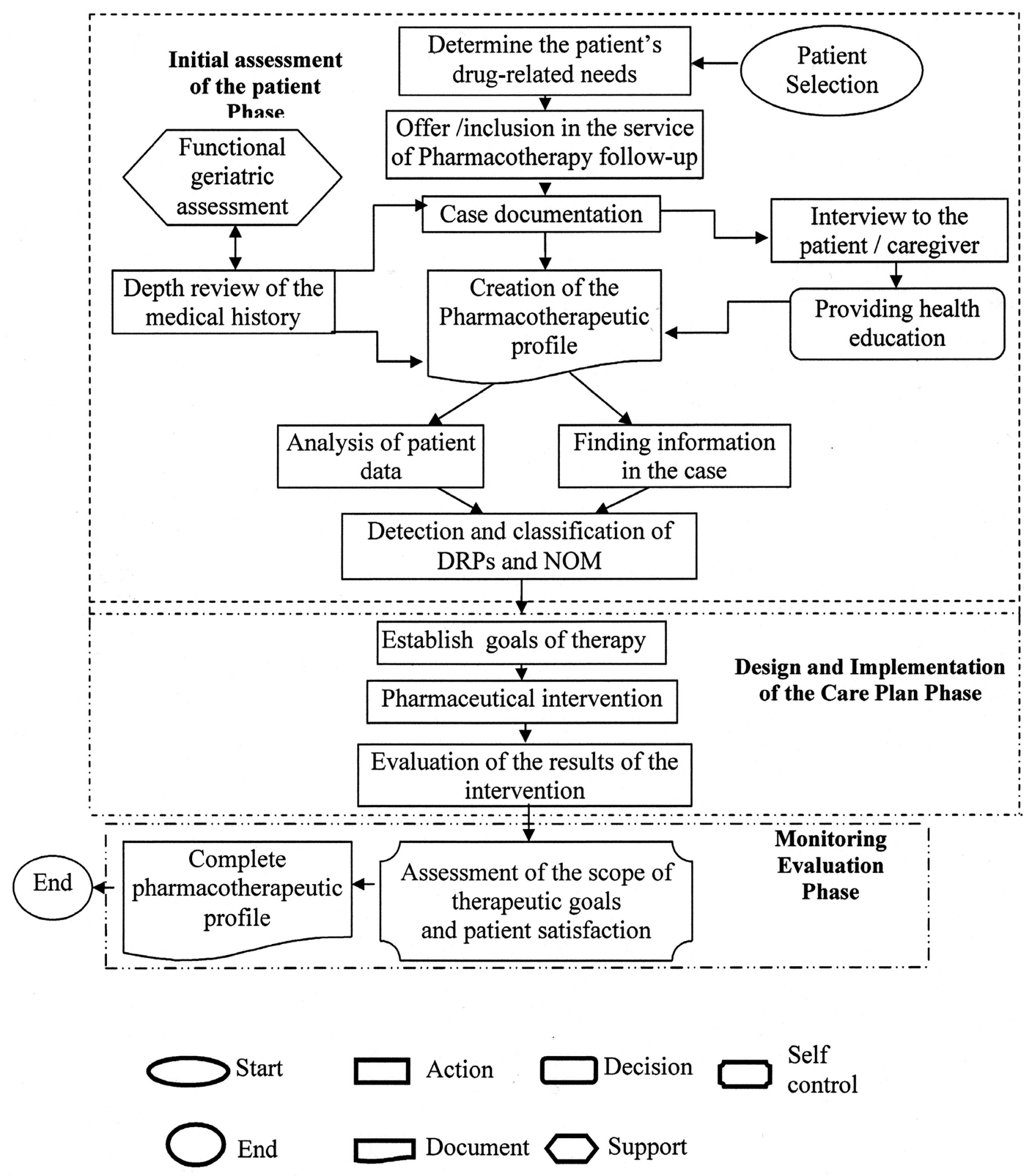

FIGURE 3 - Sequence of activities for the pharmacotherapy follow-up.

Legend: DRPs: Drugs-Related Problems. NOM: Negative Outcomes associates with Medication.

impact and adequacy of the pharmacists' interventions, pharmacotherapy results and/or clinical, pharmaco economic, humanistic outcomes, have been reported by several authors, with remarkable results in the patient's quality of life. (Climente, Jiménez, 2005).
Assessment of the SOP proposal by the experts committee (First Round)

The confidence interval values obtainedin the criteria assessment for the SOP proposal revealed a high 




FIGURE 4 - Diagram of the Standard Operating Procedure for pharmacotherapy follow-up in the elderly.

Legend: DRPs: Drugs-Related Problems. NOM: Negative Outcomes associates with Medication. 
degree of agreement among experts, which demonstrates the validity of the contents of the proposed instrument to provide pharmacotherapy follow-up for the elderly.

\section{SOP assessment reviewed by the expert committee (Second Round)}

The mean and CI values of the suggestions under evaluation by the experts, likely showed a high degree of agreement among experts. It was possible to re-design the SOP initial version and to achieve a content validity of the final reviewed instrument, to provide pharmacotherapy follow-up for the elderly.

Through the SOP analyses, no restrictions to nursing homes were introduced and the possibility of applicability at any level of health care for the elderly was recommended. The inclusion of code (01) for identifying the document, which will make possible the differentiation from other versions, which may appear with respect to the values of the of quality assurance indicators.

To respond the experts' criterion regarding the definition of stages in section "Sequence of activities", Cipolle, Strand and Morley (2004) and Dupotey (2013) criteria, were used.

\section{Limitations to this study}

Despite ensuring the anonymity of the experts who made up the panel, so as to avoid the effect of leaders, there may be the case that experts exchanged their views with each other, which can lead to information bias.

\section{CONCLUSIONS}

The Standard Operating Procedures to provide pharmacotherapy follow-up for the elderly was designed from a detailed documentary analysis that took into account: the need for holistic care to elderly patients, the criteria of inappropriate medication for this population and the relationship between functional geriatric evaluation and the use of drugs.

Two working sessions were established to achieve the procedure content validation, which was reviewed by an expert committee using the Delphi methodology. High degree of agreement among evaluators, was achieved, which allowed to improve the initial version of the instrument and to construct the final procedure.

The validated SOP is a tool that can be used by pharmacists for Pharmacotherapy follow-up forthe elderly at any level of healthcare.

\section{REFERENCES}

AMERICAN GERIATRICS SOCIETY. American Geriatrics Society 2015 beers criteria update beers criteria for potentially inappropriate medication use in older adults. $J$. Am. Geriatr. Soc., v.63, n.11, p.2227-46, 2015.

BARRY, P.J.; O'KEEFE, N.; O'CONNOR, K.A.; $\mathrm{O}^{\prime} \mathrm{MANHONY}$, D. Inappropriate prescribing in the elderly: a comparison of the Beers criteria and the improved prescribing in the elderly tool (IPET) in acutely ill elderly hospitalized patients. J. Clin. Pharm. Ther., v.31, n.6, p.61726, 2006.

BASTER, J.C. Glosario de términos y definiciones: gerontología y geriatría. La Habana, Cuba: Editorial Ciencias Médicas, 2010. p.24-38.

BLANCO-REINA, E.; ARIZA-ZAFRA, G.; OCAÑA-RIOLA, R.; LEÓN-ORTIZ, M. 2012 American Geriatrics Society Beers criteria: Enhanced applicability for detecting potentially inappropriate medications in European older adults? A comparison with the screening tool of older person's potentially inappropriate prescriptions. $J$. Am. Geriatr. Soc., v.62, n.7, p.1217-1223, 2014.

BEERS, M.H.; BERKOW, R. (Eds.). The manual Merck de geriatría. 2. ed. Madrid: Editorial Elsevier, 2001. (CDROM).

CIPOLLE, R.J.; STRAND, L.M.; MORLEY, P.C. Pharmaceutical care practice: the clinicians guide. New York: McGraw Hill, 2004. p.202-276.

CLIMENTE, M.; JIMÉNEZ, N.V. Manual para la Atención Farmacéutica. 3.ed. Valencia: AFAHPE; Hospital Universitario Dr. Peset, 2005. p.11-20; 48-58; 99-106.

COMITÉ DE CONSENSO. GIAF-UGR, GIFAF-USE, GIFUGR. Tercer consenso de Granada sobre problemas relacionados con medicamentos (PRM) y resultados negativos asociados a la medicación (RNM). Ministerio de Sanidad y Consumo. Ars. Pharm., v.48, n.1, p.5-17, 2007.

CORNELLI, R.; KRADJAN, W.; KODA-KIMBLE, M.A.; YOUNG, L.; GUGLIELMO, B.J.; ALLDREDGE, B. Assessment of therapy and pharmaceutical care. Apud: KODA-KIMBLE, M.A. Applied therapeutics: the clinical use of drugs. 8. ed. Baltimore: Lippincott Williams \&Wilkins, 2005. p.1-22. 
DALKEY, N.C. Delphi. P-.3704 RAND Santa Mónica. California: RAND Corp., 1967. 14p.

DONABEDIAN, A. The quality of care: How can it be assessed? JAMA, v.260, n.12, p.1743-48, 1988.

DUPOTEY, N.M. Paradigma de atención farmacéutica con un enfoque holístico. 2013. Trabajo presentado en opción al grado científico de Doctor en Ciencias Farmacéuticas, Universidad de la Habana, Cuba, 2013.

FARIÑAS, L. Los retos de envejecer. Periódico Granma, Cuba, 14 de Noviembre del 2013. Disponible en: <www.granma. $\mathrm{cu} / \mathrm{granmad} / 2013 / 11 / 14 /$ nacional/artic01.html $>$. Acceso en: 16 nov. 2013.

FAUS, M.; AMARILES, P.; MARTÍNEZ, F. Atención farmacéutica: conceptos, procesos y casos prácticos. Madrid: ERGON, 2008. p.87-138.

FICK, D.M.; SEMLA, T.; BEIZER, J.; BRANDT, N.; DOMBROWSKI, R.; FLANAGAN, N. American Geriatrics Society updated Beers criteria for potentially inappropriate medication use in older adults. J. Am. Geriatr. Soc., v.60, n.4, p.616-31, 2012.

FICK, D.M.; COOPER, J.W.; WADE, W.E.; WALLER. J.L.; MACLEAN, J.R.; BEERS, M.H. Updating the Beers criteria for potentially inappropiate medication use in older adults: results of a US consensus panel of experts. Arch. Intern. Med., v.163, n.22, p.2716-24, 2003.

FILOMENA, J.; GARCÍA, M.; REDONDO, F.J.; FERNÁNDEZ, M.I. Prescripción inadecuada en pacientes polimedicados mayores de 64 años en atención primaria. Atención Primaria, v. 47, n.1, p.38-47, 2014.

FIOLAVÁ, D.; TOPINKOVÁ, E.; GAMBASSI, G.; FINNESOVERI, H.; JÓNSSON, P.V.; CARPENTER, I.; SCHROLL, M.; ONDER, G.; SØRBYE, L.W.; WAGNER, C.; REISSIGOVÁ, J.; BERNABEI, R.; AdHOC PROJECT RESEARCH GROUP. Potentially inappropriate medication use among elderly home care patients in Europe. JAMA, v.293, n.11, p.1348-58, 2005.

GALLAGHER, P.; RYAN, C.; BYRNE, S.; KENNEDY, J.; O’MAHONY, D. STOPP (Screening Tool of Older Person's Prescription) and START (Screening Tool to Alert doctors to Right Treatment): consensus validation. Int. J. Clin. Pharmacol. Ther., v.46, n.2, p.72-83, 2008.
GARCÍA-GOLLARTE, F.; BALERIOLA-JÚLVEZ, J.; FERRERO-LOPEZ, I.; CRUZ-JENTOFT, A.J. Inappropriate drug prescription at nursing home admission. J. Am. Med. Dir. Assoc., v.13, n.1, Article 83.e9-15, 2012.

GAVILÁN, E.; VILlAFAINA, A.; ARÁNGUEZ, A.; SÁNCHEZ, G.A.; SULIMAN, S.; JIMÉNEZ, L. Índice de adecuación de los medicamentos. Versión española modificada manual de usuarios. 2012. Disponible en: <www.polimedicado.com>. Acceso en: 08 sept. 2012.

GÓNGORA, L.; PUCHE, E.; GARCÍA, J.; LUNA, J.D. Prescripciones inapropiadas en ancianos institucionalizado. Rev. Esp. Geriatr. Gerontol., v.39, p.19-24, 2004.

GUTIÉRREZ, L. Registros e indicadores de calidad asistencial. Desarrollo del documento de consenso sobre atención farmacéutica. 2006. Trabajo presentado en Opción al Título de Doctor en Ciencias, Universidad de Granada, España, 2006.

HANLON, J.; SCHMADER, K.; SAMSA, G.; WEINBERGER, M.; UTTECH, K.; LEWIS, I.; COHEN, H.J.; FEUSSNER, J.R. A method for assessing drug therapy appropriateness. J. Clin. Epidemiol., v.45, n.10, p.1045-51, 1992.

HOLT, S.; SCHMIEDL, S.; THURMANN, P.A. Potentially inappropriate medications in the elderly: the PRISCUS list. Dtsch. Arztebl. Int., v.107, n.31-32, p.543-51, 2010.

HURTADO, S. Criterio de expertos: Su procesamiento a través del método Delphi. 2002. Disponible en: <http://www. ub.edu/histodidactica/index.php?option $=$ com_content $\& v i$ ew $=$ article \&id=21:criterio-de-expertos-su-procesamientoa-traves-del-metodo-delphy\&catid=11:metodologiayepistemologia\&Itemid=103>. Access: 11 jun. 2014.

JANO, E.; APARASU, R. Health care, outcomes associated with Beers 'Criteria: a systematic review. Ann. Pharmacother., v.41, n.3, p.438-48, 2007.

JIMÉNEZ, M.M. A la Cuba de 2030. Periódico Juventud Rebelde, Martes 30 de Abril 2013. Disponible en: <www. juventudrebelde.cu/cuba/2013-04-29/mirada-a-la-cubade-2030>. Access: 30 abr. 2013

MEDEIROS, E.F.; MORAES, C.F.; KARNIKOWSKI, M.; NÓBREGA, O.T.; KARNIKOWSKI, M.G.O. Intervenção interdisciplinar enquanto estratégia para o uso racional de medicamentos em idosos. Ciênc. Saúde Coletiva, v.16, n.7, p.3139-49, 2011. 
MERINO, A.S.; MIGUEL, F.G.; SANZ, R.C. Yomedicalizo, túmedicalizas, él... reflexiones y propuestas. AMF., v.1, n.5, p.269-78, 2005. Apud: GARCÍA, M. La evidencia científica y la intervención farmacológica preventiva en geriatría. Rev. Cubana Med. Gen. Integr., v.28, n.4, p.747-755, 2012.

MINISTERIO DE SALUD PÚBLICA. Cuba. Anuario estadístico de salud 2015. La Habana, 2016. 208p.

NORMAS ISO 9001-2008. Sistema de gestión de la calidad: requisitos. Disponible en: <http://www.esu.com.co/esu/ documentos/normatividad/Norma\%20ISO9001\%202008. pdf>. Access: 11 feb. 2012.

OFICINANACIONAL DE ESTADÍSTICAE INFORMACIÓN. ONEI. República de Cuba: el envejecimiento de la población: Cuba y sus territorios. 2015. Disponible en: $<$ http://www.one.cu>. Access 16 may. 2016.

OFICINANACIONAL DE ESTADÍSTICAE INFORMACIÓN. ONEI. La esperanza de vida: 2011-2013: cálculos para Cuba y Provincias por sexo y edades. Disponible en: $<$ http://www. one.cu/publicaciones/cepde/esperanzadevida2011_2013/8_ la_esperanza_de_vida_por_sexo_y_edad.pdf $>$. Access 14 Nov. 2013.

ORGANIZACIÓN PANAMERICANA DE LA SALUD. ORGANIZACIÓN MUNDIAL DE LA SALUD. OPS/ OMS. El papel del farmacéutico en el sistema de atención a la salud. Informe de la Reunión de la OMS, Tokío, Japón, 31 de Agosto de 1993. Disponible en: <http://www.ops. org.bo/textocompleto/ime9848.pdf>. Access: 11 Feb. 2012.

PEÑA, M.A.; REDONDO, G.A.; GRONING, E. Consumo de medicamentos en ancianos. Rev. Cubana Med. Gen. Integr., v.19, n.3, 2003. Disponible en: <http://scielo.sld.cu/scielo. php?script=sci_arttext\&pid=S0864-21252003000300007>. Access: 23 jun 2012.

REYES, A.; PÉREZ, G.; MARTÍNEZ, G. Errores en la medicación del adulto mayor en el área de salud del Policlínico Universitario, Plaza, Ciudad de La Habana. Rev. Cubana Farm., v.40, n.3, p. 1-11, 2006. Disponible en: <http://www.bvs.sld.curevistasfarvol40_3_06far05306. htm.htm>. Access:22 mayo. 2014.

REYES, I. Estrategia para implementar el ejercicio de la atención farmacéutica en instituciones hospitalarias de la provincia de Santiago de Cuba. 2012. Trabajo presentado en opción al grado científico de Doctor en Ciencias Farmacéuticas, Universidad de la Habana, Cuba, 2012.
REYES, I.; BERMÚDEZ, I.B.; STORPIRTIS, S.; BARANDA, S.C.; FERNÁNDEZ, E.S. Sistema organizativo para implementar el ejercicio de la Atención Farmacéutica Hospitalaria en Santiago de Cuba. Rev. Cubana Farm., v.48, n.3, p. 432-45, 2014. Disponible en: <http://bvs.sld. cu/revistas/far/vol48_3_14/far10314.htm>. Access: 06 feb. 2015 .

REYES, I.; CRUZATA, Y.; VIDAL, M.; BERMÚDEZ, I.; NAMBATYA, W.; PERRAND, M.; DUTOK, C.M. Evaluación de un procedimiento para brindar seguimiento farmacoterapéutico a pacientes hospitalizados. Rev. Mex. Cienc. Farm., v.44, n.1, p.66-78, 2013.

SILVA-CASTRO, M.M.; CALLEJA, M.A.; MACHUCA, M.; FAUS, M.J.; FERNÁNDEZ-LLIMÓS, F. Seguimiento farmacoterapéutico a pacientes hospitalizados: adaptación del Método Dáder. Seguim. Farmacoter., v.1, n. 2, p.73-81, 2003.

SILVEIRA, E.; ERRASQUÍN, B.; GARCÍA, M.; VÉLEZDÍAZ-PALLARÉS, M.; MONTOYA, I.; SÁNCHEZCASTELLANO, C.; CRUZ-JENTOFT, A. Mejorando la prescripción de medicamentos en las personas mayores: una nueva edición de los criterios STOPP-START. Rev. Esp. Geriatr. Gerontol., v.50, n.2, p.89-96, 2015.

SOTOCA, J.M.; ANGLADA, H.; MOLAS, G.; FONTANALS, S.; ROVIRA, M.; SEBASTIÁN, L. Aplicación de los nuevos criterios de prescripción inadecuada STOPP-START a pacientes geriátricos institucionalizados. Farmacéuticos de Atención Primaria, v.9, n.1, p.2-7, 2011.

STUIJT, C.; FRANSSEN, E.; EGBERTS, A.; HUDSON, S. Appropriateness of prescribing among elderly patients in a Dutch residential home: observational study of outcomes after a pharmacist-led medication review. Drugs Aging, v.25, n.11, p.947-54, 2008.

SUÁREZ, N. Caracterización epidemiológica del consumo de medicamentos por la población adulta de Cuba. 20072010. Trabajo presentado en opción al grado científico de Doctor en Ciencias de la Salud, Escuela Nacional de Salud Pública, Cuba, 2011. 
WIDENMAYER, K.; SUMMERS, R.S.; MACKIE, C.A. Desarrollo de la práctica de farmacia centrada en la atención del paciente. Organización Mundial de la Salud y Federación Internacional Farmacéutica. MANUAL. Ginebra: OMS, 2006. Disponible en: <http://www.fip. org/files/fip/publications/DevelopingPharmacyPractice/ DevelopingPharmacyPracticeES.pdf $>$. Access: 13 mayo 2014.

Received for publication on $27^{\text {th }}$ October 2015 Accepted for publication on $19^{\text {th }}$ December 2016 